УДК 640.41

DOI: https://doi.org/10.26642/jen-2020-1(91)-60-65

А.О. Чагайда, к.т.н., доц.

Державний університет «Житомирська політехніка»

\title{
Тенденції розвитку комплексу додаткових послуг для створення конкурентних переваг готелю
}

\begin{abstract}
Готельні комплекси пропонують значну кількість послуг, які спрямовані на задоволення певних бажань споживачів. На сьогоднішній день невпинно зростає кількість спожсиачів, яких не влаштовує одноманітність стандартних готелів і при плануванні відпочинку вони звертають особливу увагу на екологічні аспекти подорожей і розмімення, місиезнаходження закладу та стан території, вид та особливість будівлі, комфортність і дизайн приміщень. Мандрівники хочуть, щуоб готелі, в яких вони зупиняються, брали участь в екоакиіях і програмах, оскільки збереження навколишнього середовища для багатьох має пріоритетне значення. У статті обтрунтована дочільність надання додаткових послуг у сучасних готелях задля забезпечення конкурентних переваг на ринку таких послуг. Визначено, щуо для залучення гостя в готель, як свідчить практика маркетингу та теорї брендингу, необхідно використовувати мультисенсорний маркетинг. Окрім того, підтверджено, щзо для закладу розмішення є вісім обов'язкових ознак із переліком послуг, щзо відповідають високому рівню готелю: персоналізована послуга преміумкласу, доступ до безпечного сховища, безкоштовний доступ до мережі Internet, брендований одяг для ванни, иілодобове обслуговування номерів, розкішні меблі та постільні речі, персональне обслуговування консьєржа/покоӥвки, місие розташування. Визначено пріоритетні напрями розвитку додаткових послуг готелю, оскільки подальший розвиток індустрї гостинності вже практично неможливий без використання сучасних технологій по залученню клієнтів, водночас саме акцент на додаткові послуги може стати вирішальним фактором обрання закладу розміщення.
\end{abstract}

Ключові слова: готель; конкурентні переваги; послуги; розвиток; заклад розміщення.

Постановка проблеми в загальному вигляді та ії̈ зв'язок 3 практичними завданнями. Сучасна індустрія гостинності 3 кожним роком стає все більш різноманітною, адже головною метою роботи готелів $є$ задоволення потреб людини в сучасних умовах проживання та харчуванні. Готельні комплекси пропонують значну кількість послуг, які спрямовані на задоволення певних бажань споживачів. За визначенням відомого американського фахівця з маркетингу Ф.Котлера (Philip Kotler), послуга - це будь-який захід або вигода, які одна сторона може запропонувати інший, i які, в основному, невідчутні [1]. Послуга, в широкому значенні, містить усі ті переваги, що отримує споживач, який погоджується на придбання певного продукту: доступність готелю, його загальну атмосферу, легкість у спілкуванні клієнтів з обслуговуючим персоналом, їх участь у процесі обслуговування і взаємодію клієнтів один з одним [2].

Люди як особистості завжди мають якісь потреби, різноманітність та якість яких залежить від способу і умов життя, приналежності до якоїсь соціальної групи [3]. Потреба зазвичай виникає за наявності у людини почуття незадоволеності, пов'язаного з дефіцитом необхідного для особистості, стимулює на пошук потрібного, призводить до стану підвищеної збудливості окремі психічні процеси і органи, підтримує активність організму до того часу, поки відповідний стан потреби не буде повністю задоволений [4]. При виборі готельного комплексу споживачі обирають не просто кімнату для тимчасового проживання, й сервіс та культуру обслуговування. Ці нематеріальні складові здебільшого є визначальними при ухваленні рішення на користь остаточного варіанта. Разом із тим, суттєвою проблемою для закладів розміщення є значні сезонні коливання попиту, що стримує вкладання значних коштів у великі готельні комплекси [5].

Аналіз останніх досліджень та публікацій. Дослідженням проблем додаткових послуг у готелях, особливостей і принципів взаємодії з основними послугами готелів для задоволення потреб споживачів займалось багато зарубіжних та вітчизняних вчених, таких як: Дж.Ердош, Р.Браймер, Дж.Р. Уокер, К.С. Погодін, І.Г. Смирнов, Н.О. П’ятницька, В.В. Архіпов, В.А. Русавська та ін.

Метою статті є дослідження тенденцій комплексу додаткових послуг для створення конкурентних переваг готелей в Україні.

Викладення основного матеріалу. Прогнозовані у майбутньому витрати на поїздки для споживачів будуть становити 1,26 трильйона доларів США до 2022 року, і бренди, які хочуть отримати частину цих грошей, мають запропонувати споживачам найкращі послуги та більш індивідуальний підхід. Результати опитування американських респондентів свідчать, що лише 23 \% надзвичайно або дуже лояльні до певного бренда чи мережі готелів, водночас 30 \% висловлюють зацікавленість у більш персоналізованому 
підході [6]. У 2017 році компанія Intercontinental Hotels Group (IHG) на Всесвітньому економічному форумі (WEF) у швейцарському Давосі представила свій черговий п’ятий звіт із серії досліджень тенденцій ринків із аргументованими порадами брендам для їх подальшої відповідності майбутньому попиту споживачів. Цей звіт, iз промовистою назвою «Безкомпромісний споживач: парадокси епохи зростаючої персоналізації», акцентує увагу на високій вимогливості сучасного клієнта, який чекає від готельних брендів задоволення широкого спектру певною мірою суперечливих запитів та на небажанні клієнтів йти на будь-які компроміси. Дослідження IHG, викладене у цьому звіті, виявило чотири парадокси, що є визначальними під час прийняття споживчих рішень в умовах динамічного розвитку технологій. У цьому середовищі клієнти не хочуть рішення або/або: вони хочуть найкращого 3 обох світів, де найкращий компроміс - це зовсім не компроміс. Ці чотири парадокси були сформульовані таким чином:

- парадокс відокремленого, але пов'язаного: бажання постійного зв'язку з людьми, брендами i місцями, при одночасному прагненні підкреслити свою індивідуальність та унікальність;

- парадокс одночасного достатку та рідкості: бажання, щоб розкіш була дефіцитною, але завжди доступною;

- парадокс пошуку кращого «себе» та кращого «нас»: прагнення особистого самовдосконалення, при одночасному бажанні досягти поліпшення громадського, громадянського чи глобального рівня;

- парадокс «зробіть це, наче я зробив те сам» та «зробіть те для мене по-своєму»: бажання контролювати все, не будучи контролером [7].

Один із головних висновків IHG полягає у необхідності підтримки постійного контакту з клієнтами шляхом прямого спілкування: бренди мають слухати клієнтів, щоб зрозуміти їхні потреби та отримати більш значущий досвід у розумінні їх парадоксів та бажань.

Для визначення ступеня задоволення гостя засоби розміщення можуть враховувати такі основні групи показників: загальне емоційне враження від проживання; оцінка якості харчування; оцінка інтер'єрів; вирішення проблем персоналом готелю; ставлення персоналу; ефективність роботи персоналу; доступність і повнота інформації про заходи та об'єкти на території готелю [8]. Найбільш поширеною концепцією оцінки якості послуги $є$ п'ятиступенева модель якості послуги або модель розбіжності якості послуги, розроблена та вперше опублікована у 1985 році американськими вченими А.Парасураманом (A.Parasuraman), В.Зейтамль (Valarie A. Zeithaml) і Л.Берpi (Leonard L. Berry) [9]. Логічним продовженням цієї концепції став практичний інструмент оцінки якості послуги - методика SERVQUAL (скор. від Service Quality), яка опублікована тим же колективом авторів у 1988 році [10]. На сприйняття споживачів впливає багато чинників, як-от вербальне спілкування, особисті потреби, минулий досвід і організація, що проводить обслуговування, а методика SERVQUAL фіксує та аналізує розбіжності, що призводять до головного: споживач очікує одного, а отримує, на його думку, інше. Якщо споживач отримав менше, ніж очікував, то він буде сильно розчарований, а якщо послуга перевершує його очікування - то це не тільки його влаштовує, але і захоплює.

Інша концепція, яку розробили професори маркетингу у сфері готельного та ресторанного бізнесу із США і Канади Е.P. Кедотт (Ernest R. Cadotte) і Н.Терджен (Normand Turgeon), грунтується на аналізі і оцінці характеру сприйняття споживачем обслуговування через так звану типологію елементів обслуговування яка містить чотири класифікаційні групи елементів: критичні; нейтральні; ті, що приносять задоволення; ті, що приносять розчарування [11].

Для справді розкішного закладу розміщення є 8 обов'язкових ознак із певним переліком послуг, що відповідають високому рівню готелю:

1. Персоналізована послуга преміумкласу. У готелях з найвищим рейтингом персонал проходить навчання для надання персоналізованого обслуговування: впізнають клієнта за іменем; знають деякі, якщо не всі, вподобання гостя; зроблять усе можливе, щоб клієнт почувався особливим;

2. Доступ до безпечного сховища. Люди, які подорожують та користуються розкішними приміщеннями, можуть мати із собою важливі активи, дорогий одяг та ювелірні вироби преміумкласу. Розкішні готелі знають про це і забезпечують гостям доступ до сейфів та безпечних сховищ;

3. Безкоштовний доступ до мережі Internet. Як це не дивно, але багато готелів все ще надають доступ до мережі Internet за окрему плату. Якщо у розкішному номері немає безкоштовного Wi-Fi, то цей номер не відповідає заявленому рівню;

4. Брендовані плюшеві халати для ванни. Елітні готелі дотепер пропонують гостям вишукані фірмові плюшеві халати для використання в номері, спа-салоні та зоні біля басейну. У багатьох випадках халати жадані для гостей та доступні для придбання;

5. Цілодобове обслуговування номерів. Люди з грошима не прагнуть жити за загальними правилами i мають тенденцію дотримуватися дивних графіків. 3 цієї причини готелі для багатих і відомих зазвичай підтримують обслуговування номерів 24/7;

6. Розкішні меблі та постільні речі. У розкішному готельному номері, перше, що впадає в око, буде зона відпочинку, а вже потім спальний куточок або окрема спальня; 
7. Персональне обслуговування консьєржа/покоївки. Якщо це готель преміумкласу, то гостям може бути надано доступ до консьєржа чи покоївки, завданням яких є виконання всіх побажань і потреб клієнтів;

8. Місце розташування. Варто очікувати прекрасний вид (океан, гори, вогні міста) та доступ до кращих ресторанів і розважальних майданчиків [12].

Якщо клієнтові не підтверджують отримання послуг та зручності із зазначеного вище переліку, то варто продовжувати пошуки і знайти інший готель відповідного рівня. Необхідно зазначити, що час вносить зміни у ставлення споживачів до поняття «розкіш» і вишуканість вже перестала бути обов'язковою відмінною рисою розкішного готелю. Споживачі, які мають великі гроші, витрачають їх зовсім іншим чином, ніж то робилося на 10 років раніше: якщо вони не обтяжують себе у виборі одягу під час роботи, то, відповідно, не хочуть те робити і під час відпочинку й одягати костюм для вечері в ресторані.

Дорогі готелі заохочують клієнтів зупинятися в них різними додатковими послугами. При бронюванні номера в готелі Four Seasons як бонус можна отримати ключі від автомобіля «Rolls Royce Phantom» або «Maybach», які будуть у розпорядженні клієнта на весь період бронювання готелю. Також для підкреслення максимальної гостинності при заселенні в готелях пропонують елітний віскі або пляшку текіли Don Julio, як це прийнято в Mandarin Oriental у Mехіко. Тим, хто притримується здорового способу життя пропонують ексклюзивні сорти китайських чаїв або, як у готелі Mandarin Oriental в Омані, зустрічають постояльців чашкою арабської кави [13].

Елізабет Мартин (Elizabeth Martyn) та Кріс К. Андерсон (Chris K. Anderson) з Центру досліджень готельного господарства Корнельського університету зазначають, що технології змінили динаміку взаємодії гостей в індустрії гостинності. Двома ключовими елементами цієї зміни є те, що зараз у постачальників послуг $\epsilon$ менше можливостей для безпосереднього спілкування з гостями, і взаємодія часто може бути результатом збою у системі надання послуг. Під час зустрічей віч-на-віч здатність співробітників ефективно керувати емоційними компонентами взаємодії 3 клієнтами може стати вагомим внеском у задоволення гостя результатом [14]. Кріс К. Андерсон, який є директором цього центру досліджень, вважає, що індустрія гостинності зараз має розпочати нову главу, адже гості шукають більш насичені індивідуальні стосунки та безперешкодне спілкування зі своїми постачальниками гостинності і готові ділитися великою кількістю власних даних та думок більшою мірою, ніж будь-коли раніше.

Компанія Booking.com у 2018 році провела опитування 3-поміж 20500 респондентів по всьому світі, щоб з'ясувати, які труднощі заважають мандрівникам отримувати задоволення від поїздок і як ці труднощі подолати. Дослідження показало, що значна частина респондентів (63 \%) проводить відпустку не так, як їм хотілося б, а 20 \% респондентів ніколи не відчували повну свободу під час поїздки, водночас майже половина респондентів (44 \%) прагне стати «мандрівниками без кордонів», а 78 \% мріє використати всі можливості під час відпочинку і ні про що не шкодувати. В результаті опитування 3'ясувалося, що 62 \% мандрівників хочуть познайомитися з новими культурами, $51 \%$ - спробувати місцеві страви, $39 \%$ - зупинитися в незвичайному об'єкті розміщення, а $33 \%$ - познайомитися 3 новими людьми. Більша частина респондентів (55 \%) зазначили, що люблять подорожі за можливість вийти із зони комфорту і отримати унікальні враження від поїздки, в тому числі варіанти найпопулярніших відповідей передбачали волонтерську поїздку (39 \%), гастротур (38 \%), поїздку по містичними місцями (38\%) тощо. Разом із тим, 34 \% гостей при плануванні турбуються, що не зможуть знайти підходящий варіант проживання, а $26 \%$ - що потраплять в непередбачену ситуацію під час поїздки. Більшість респондентів вважає, що сучасні технології дозволяють частково подолати ці хвилювання за рахунок широкого вибору варіантів житла (37 \%) та позитивних відгуків інших мандрівників (35 \%) [15]. Для мінімізації цих застережень та хвилювань потенційних споживачів послуг найбільш відомий сервіс iз бронювання житла Booking.com. постійно збільшує базу об'єктів розміщення клієнтів (рис. 1) та удосконалює можливості для такого бронювання за допомогою сайту. Для полегшення пошуку команда Booking.com постійно експериментує над адаптацією програми до вимог клієнтів, що призводить до змін у окремих частинах сайту практично кожні 5-10 хвилин [16].

Дослідження смаків молодих мандрівників, проведене у 2017 році New Horizons, показало, що $67 \%$ iз них воліють бронювати житло через онлайн-агентства та інші посередницькі організації, а не безпосередньо через готелі. Серед молоді найпопулярнішим в світі онлайн-агентством для бронювання житла є Booking.com, послугами якого користуються 40\% мандрівників молодше 30 років, а ще $23 \%$ бронюють житло на Airbnb [17].

Airbnb створює значну конкуренцію готелям, через постійно зростаючі пропозиції (більше 3 мільйонів) і низькими витратами входження операторів, та вже обслуговує понад 200 мільйонів мандрівників, що більш ніж у 65 тисячах міст усього світу. Окрім того, Airbnb намагається стати повнофункціональною компанією з надання туристичних послуг, придбавши кілька компаній цього профілю та готова вийти на ринок нерухомості, що йде врозріз з тенденцією полегшення активів готелями. Так Airbnb має намір інвестувати 200 мільйонів доларів у проект брендованих апартаментів в різних містах США, водночас орендарі цих апартаментів отримають дозвіл здавати їх на Airbnb протягом 180 днів на рік, відповідно 
перераховуючи частину прибутку компанії. Комплекси апартаментів будуть створені в характерному для Airbnb стилі, що містить доступ без ключів і спільні загальні зони. Водночас Airbnb активно удосконалює свої продукти для бізнес-мандрівників, запустивши спеціальний сайт і надання чітких інструкцій господарям житла, щоб допомогти їм зробити свої апартаменти придатними для клієнтів ділових поїздок.

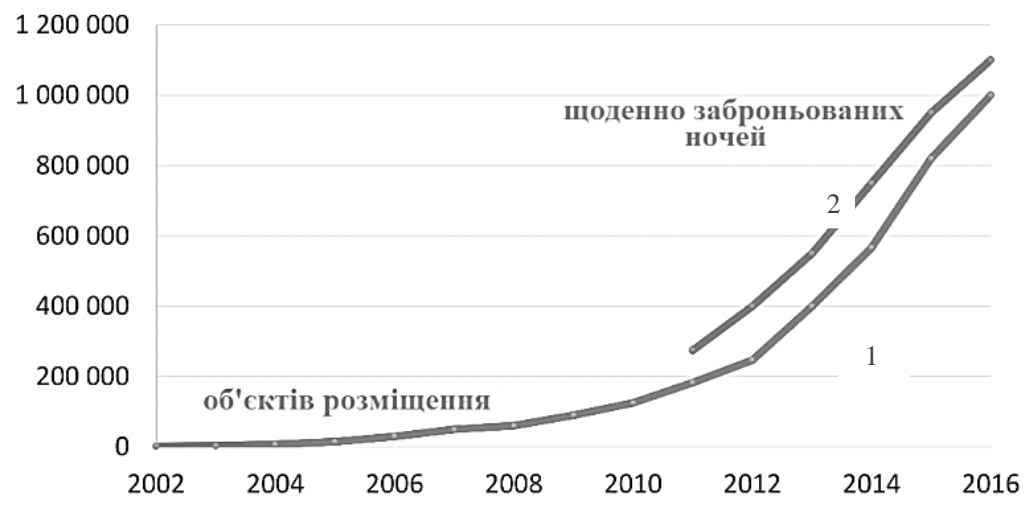

Рис. 1. Кількість об'єктів розміщення (графік 1) і кількість щзодня заброньованих ночей (графік 2) через Booking.com

Стратегії протидії Airbnb зі сторони готельних мереж полягають у вимогах до законодавців вводити більш суворі правила по відношенню до операторів найму житла. Розуміючи, що цього недостатньо, готелі розвивають нові бренди, які спрямовані на задоволення різноманітних потреб різних мандрівників, зокрема і тих, які зазвичай віддають перевагу Airbnb. Наприклад, Marriott вивела на ринок кілька Моху Hotels - продукт, який, на думку компанії, може боротися 3 Airbnb, a Hyatt досягла угоди 3 The Oasis Collection, що дозволить мандрівникам бронювати «вручну відібрані» квартири і будинки, які відповідають готельним стандартам. Інша мережа Wyndham придбала Love Home Swap - стартап, який передбачає обмін будинками між мандрівниками. Також засоби розміщення намагаються спонукати клієнтів здійснювати бронювання безпосередньо на сайті готелю з гарантією найнижчої ціни на ринку, а також проводять перегляд програм лояльності, спрямований на залучення нових клієнтів із збереженням рівня задоволеності постійних гостей [18].

Сучасний готель - це не лише бездоганне обслуговування, а й атмосфера затишку та домашнього спокою, яку також допомогає створювати використання ароматичних речовин. Загальновідомо, що для залучення гостя в готель, як свідчить практика маркетингу та теорії брендингу, необхідно використовувати мультисенсорний маркетинг, принципи якого досить прості. Кожна людина сприймає навколишній світ за допомогою п'яти відчуттів: зір, слух, нюх, смак і дотик. Ці канали є нашим засобом комунікації 3 навколишнім світом та основними при прийнятті рішення, тож застосування аромамаркетингу в готельному підприємстві $є$ ефективним засобом підвищення конкурентоспроможності та здатне викликати емоційну прихильність [19]. Яскравим прикладом використання цього підходу є готель Palazzo Magnani Ferroni у Флоренції, що приділяє особливу увагу ароматам. Кожного клієнта, який бронює номер, адміністрація заздалегідь розпитує про ароматичні уподобання, які їм до душі: запах кориці вранці або густий аромат індійських пахощів буде наповнювати апартаменти, що сподобається людям із тонким нюхом [20].

Конкуренція в готельному бізнесі зростає, тому менеджерам готелів доводиться пропонувати цікаві додаткові послуги, здатні залучити і утримати відвідувачів. У жовтні 1829 року у Бостоні відбулася епохальна подія - відкрився готель «Тремон», який першим у світі здивував своїх клієнтів розкішними новинками: водопроводом і безкоштовним милом у кожному номері [21]. Сьогодні, звичайно, цим гостей не здивувати, тому готелі вигадують незвичайні послуги i процедури: акційні пропозиції для іменинників, молодят, великих компаній, екзотичні процедури та заходи. Так готель-казино Ріо, що знаходиться в Лас-Вегасі, пропонує послугу тату, щоб увічнити на власному тілі пам'ятні моменти проведення часу в столиці азарту. Культурні пробіжки пропонує готель Four Seasons Hotel George V в Парижі: постояльці можуть розім'ятися і взяти участь у дев'ятикілометровому забігу у супроводі конс'єржа по відомих місцях міста (готель - Ейфелева вежа - площа Трокадеро - сад Тюільрі - готель). Готель Giraffe Manor в Кенії пропонує обід з жирафом, адже ці тварини вільно пересуваються територією готелю і тому охоче складуть вам компанію не лише під час харчування, а і на прогулянці. Прихильники зеленого туризму, які перенасичені комфортом готелів і увагою персоналу, можуть на якийсь час перетворитися на звичайних селян у готелі Dhara Dhevi (Таїланд), де для отримання смачної вечері спочатку необхідно навчитися саджати рис і самостійно готувати будь-яку страву місцевої кухні [22].

Готель Le Royal Monceau Raffles Paris пропонує незвичну послугу - консультації арт-консьєржа Домуана де Брантеса, який є експертом із сучасного мистецтва і разом зі своєю командою розповість 
гостям про останні тенденції в світі мистецтва та актуальні культурні події Парижа. Також арт-консьєрж допоможе розробити програму і проведе екскурсію приватною колекцією готелю та галереєю Art District. Гості готелю можуть забронювати індивідуальні тури до визначних пам'яток архітектури та музеями Парижа, відвідати майстерні місцевих художників або замовити приватні уроки гри на гітарі [23].

Домінування технологій починає відігравати ключову роль під час відпочинку. Ще у 2014 році корпорація Starwood Hotels \& Resorts Worldwide, Inc. запустила Starwood Preferred Guest ${ }^{\circledR}$ (SPG $\left.{ }^{\circledR}\right)$ Keyless, мобільну та безключову систему входу, яка дозволяє гостям використовувати свій смартфон як ключ від дверей готельного номера. В подальшому ця технологія розширила свій функціонал і в 2016 році вже була доступна у більше ніж 160 готелях у більше ніж 30 країнах світу [24]. Використання смартфонів та наявність чат-ботів дозволяє мандрівникам швидко знаходити рішення з усіх стандартних запитів готельного обслуговування, а готелі мають пропонувати клієнтам такий же рівень технологій, що вони мають у повсякденному житті.

Висновки. Ринок готельно-ресторанних послуг динамічно розвивається відповідно до нових запитів клієнтів, що призводить до спеціалізації закладів розміщення при одночасному прагненні підкреслити індивідуальність та унікальність. Подальший розвиток індустрії гостинності вже практично неможливий без використання сучасних технологій по залученню клієнтів, водночас акцент на додаткові послуги може стати вирішальним фактором обрання закладу розміщення. Заклади готельно-ресторанного бізнесу для підвищення конкурентоспроможності та привабливості постійно розширюють асортимент послуг на основі застосування технічних та соціальних інновацій.

\section{Список використаної літератури:}

1. Котлер Ф. Основы маркетинга / Ф.Котлер. - М. : Прогресс, 1992. - 656 с.

2. Уокер Дж.Р. Введение в гостеприимство / Дж.Р. Уокер. - М. : Юнити-Дана, 2012. - 735 с.

3. Абрахам Маслоу и иерархия потребностей // Энциклопедия маркетинга [Електронний ресурс]. - Режим доступа : http://www.marketing.spb.ru/lib-around/maslow.htm.

4. Орлов С.В. Человек и его потребности : учеб. пособ. / С.В. Орлов. - СПб. : Питер, 2006. - 158 с.

5. Перспективи розвитку готелів у стилі глемпінг в Україні / О.В. Олійник, Т.Л. Мостенська, Г.М. Тарасюк, A.O. Чагайда // Наукове видання Державного університету «Житомирська політехніка». Серія : Економіка, управління та адміністрування. - Житомир, 2019. - № 4 (90). - С. 38-46.

6. A personalized experience? Hotels still not getting it right [Electronic recource]. - Access mode : https://www.traveldailynews.com/post/a-personalized-experience-hotels-still-not-getting-it-right.

7. The Uncompromising Customer: Addressing the Paradoxes of the Age of I [Electronic recource]. - Access mode : https://www.ihgplc.com//media/ihg/files/pdf/trendsreport/2017_trends_report.pdf?la=en\&hash=0048F454CF3818C A9D4EECDC97861644.

8. Джум Т.А. Имидж конкурентоспособной гостиницы / Т.А. Джум [Електронний ресурс]. - Режим доступа : http://journal.kfrgteu.ru/files/1/2012_09_08.pdf.

9. Parasuraman A. A Conceptual Model of Service Quality and Its Implications for Future Research / A.Parasuraman, Valarie A. Zeithaml, Leonard L.Berry // Journal of Marketing. - 1985. - Vol. 49 (4). - P. 41-50.

10. Parasuraman A. SERVQUAL: A Multiple-Item Scale for Measuring Customer Perceptions of Service Quality / A.Parasuraman, Valarie A. Zeithaml, Leonard L. Berry // Journal of retailing. - 1988. - Vol. 64 (1) Spring. - P. $12-40$.

11. Cadotte E.R. Dissatisfiers and Satisfiers: Suggestions from Consumer Complaints and Compliments / E.R Cadotte, N.Turgeon // Journal of Consumer Satisfaction, Dissatisfaction and Complaining Behavior, 1988. - Vol. 1. - P. 74-79.

12. Eight things you should expect in a luxury hotel // Daily travel \& tourism news portal for the international travel trade market. - 28 Jan. - 2020 [Electronic recource]. - Access mode : https://www.traveldailynews.com/post/eightthings-you-should-expect-in-a-luxury-hotel.

13. 10 самых необычных услуг в дорогих отелях [Электронный ресурс]. - Режим доступа : https://airlife.ua/10samyh-neobychnyh-uslug-v-dorogih-otelyah/.

14. Martyn E. Customer satisfaction through service excellence: The importance of focused training / E.Martyn, C.K. Anderson // Cornell Hospitality Report, 2018. - No. 18 (9). - P. 1-14 [Electronic recource]. - Access mode : https://scholarship.sha.cornell.edu/cgi/viewcontent.cgi?article=1264\&context=chrpubs.

15. Исследование Booking.com: основные трудности путешественников во время поездок [Электронный peсурс]. - Режим доступа : http://prohotelia.com/2018/05/travelling-difficulties/.

16. Архитектура поиска в Booking.com [Електронний ресурс]. - Режим доступа : https://habr.com/ru/post/323094/.

17. Приоритеты проживания путешествующей молодежи - хостелы, отели, Airbnb. Брони - в основном, через OTA, а не напрямую [Электронный ресурс]. - Режим доступа : http://www.pitert.ru/news/issledovanieprioritety-p http://www.pitert.ru/news/issledovanie-prioritety-p.

18. Airbnb против отельеров. Чего ожидать от противостояния в 2018-м году? [Електронний ресурс]. - Режим доступа : https://hotelier.pro/hostels/item/3236-airbnb/.

19. Менеджмент суб'єктів господарювання в умовах забезпечення сталого розвитку : кол. монографія / за заг. ред. д.е.н., проф. Тарасюк Г.М. - Житомир : ЖДТУ, 2017. - С. 283-293.

20. Самые необычные услуги гостиниц мира [Электронный ресурс]. - Режим доступа : http://domik.ua/novosti/samye-neobychnye-uslugi-gostinic-mira-n84295.html.

21. Throwback Thursday: When the First Modern Hotel in America Opened in Boston [Electronic recource]. - Access mode : https://www.bostonmagazine.com/news/2015/10/15/tremont-house/. 
22. 5 незвичайних послуг в готелях [Електронний ресурс]. - Режим доступу : https://velerosse.com.ua/ua/articles/5_neobychnyh_uslug_v_oteljah/.

23. Дорогу в мир современного искусства покажет арт-консьерж [Электронный ресурс]. - Режим доступа : http://prohotelia.com/2013/06/le-royal-monceau-raffles-paris_art-district/.

24. Starwood Expands SPG Keyless Locations and Functionality [Electronic recource]. - Access mode : https://hospitalitytech.com/starwood-expands-spg-keyless-locations-and-functionality.

\section{References:}

1. Kotler, F. (1992) Osnovy marketinga, Progress, M., 656 p.

2. Uoker, Dzh.R. (2012), Vvedenie v gostepriimstvo, Juniti-Dana, M., 735 p.

3. www.marketing.spb.ru, «Abraham Maslou i ierarhija potrebnostej», Jenciklopedija marketinga, [Online], available at: http://www.marketing.spb.ru/lib-around/maslow.htm

4. Orlov, S.V. (2006), Chelovek i ego potrebnosti, ucheb. posobie, Piter, SPb, 158 p.

5. Olijnik, O.V., Mostens'ka, T.L., Tarasjuk, G.M. and Chagajda, A.O. (2019), «Perspektivi rozvitku goteliv u stili glemping v Ukraïni», Naukove vidannja Derzhavnogo universitetu «Zhitomirs'ka politehnika» Serija : Ekonomika, upravlinnja ta administruvannja, Zhitomir, No. 4 (90), pp. 38-46.

6. www.traveldailynews.com, A personalized experience? Hotels still not getting it right, [Online], available at: https://www.traveldailynews.com/post/a-personalized-experience-hotels-still-not-getting-it-right

7. www.ihgplc.com, The Uncompromising Customer: Addressing the Paradoxes of the Age of I, [Online], available at: https://www.ihgplc.com//media/ihg/files/pdf/trendsreport/2017_trends_report.pdf?la=en\&hash=0048F 454CF3818CA9D4EECDC97861644

8. Dzhum, T.A. Imidzh konkurentosposobnoj gostinicy, [Online], available at: http://journal.kfrgteu.ru/files/1/2012_09_08.pdf

9. Parasuraman, A. Zeithaml, V.A. and Berry, L.L. (1985), «A Conceptual Model of Service Quality and Its Implications for Future Research», Journal of Marketing, No. 49 (4), pp. 41-50.

10. Parasuraman, A. Zeithaml, V.A. and Berry, L.L. (1988), «SERVQUAL: A Multiple-Item Scale for Measuring Customer Perceptions of Service Quality», Journal of retailing, No. 64 (1) Spring, pp. 12-40.

11. Cadotte, E.R. Turgeon, N. (1988), «Dissatisfiers and Satisfiers: Suggestions from Consumer Complaints and Compliments», Journal of Consumer Satisfaction, Dissatisfaction and Complaining Behavior, No. 1, pp 74-79.

12. www.traveldailynews.com (2020), «Eight things you should expect in a luxury hotel», Daily travel \& tourism news portal for the international travel trade market, from 28 Jan., [Online], available at: https://www.traveldailynews.com/post/eight-things-you-should-expect-in-a-luxury-hotel

13. 10 samyh neobychnyh uslug $v$ dorogih oteljah, [Online], available at: https://airlife.ua/10-samyh-neobychnyhuslug-v-dorogih-otelyah/

14. Martyn, E. and Anderson, C.K. (2018) «Customer satisfaction through service excellence: The importance of focused training», Cornell Hospitality Report, No. 18 (9), pp. 1-14, [Online], available at: https://scholarship.sha.cornell.edu/cgi/viewcontent.cgi?article=1264\&context=chrpubs

15. Issledovanie Booking.com: osnovnye trudnosti puteshestvennikov vo vremja poezdok, [Online], available at: http://prohotelia.com/2018/05/travelling-difficulties/

16. Arhitektura poiska v Booking.com, [Online], available at: https://habr.com/ru/post/323094/

17. Prioritety prozhivanija puteshestvujushhej molodezhi-hostely, oteli, Airbnb. Broni-v osnovnom, cherez OTA, a ne naprjaтијu, [Online], available at: http://www.pitert.ru/news/issledovanie-prioritety-p http://www.pitert.ru/news/issledovanie-prioritety-p

18. Airbnb protiv otel'erov. Chego ozhidat' ot protivostojanija $v$ 2018-m godu?, [Online], available at: https://hotelier.pro/hostels/item/3236-airbnb/

19. Tarasjuk, G.M. and al (2017), Menedzhment sub'jektiv gospodarjuvannja v umovah zabezpechennja stalogo rozvytku, kol. Monografija, in Tarasjuk G.M. (ed.), ZhDTU, Zhytomyr, pp. 283-293.

20. Samye neobychnye uslugi gostinic mira, [Online], available at: http://domik.ua/novosti/samye-neobychnye-uslugigostinic-mira-n84295.html

21. www.bostonmagazine.com (2015), Throwback Thursday: When the First Modern Hotel in America Opened in Boston, [Online], available at: https://www.bostonmagazine.com/news/2015/10/15/tremont-house/

22. 5 nezvichajnih poslug $v$ goteljah, [Online], available at: https://velerosse.com.ua/ua/articles/5_neobychnyh_uslug_v_oteljah/

23. Dorogu $v$ mir sovremennogo iskusstva pokazhet art-kons'erzh, [Online], available at: http://prohotelia.com/2013/06/le-royal-monceau-raffles-paris_art-district/

24. Starwood Expands SPG Keyless Locations and Functionality, [Online], available at: https://hospitalitytech.com/starwood-expands-spg-keyless-locations-and-functionality

Чагайда Андрій Олегович - доцент, кандидат технічних наук, доцент кафедри туризму та готельноресторанної справи Державного університету «Житомирська політехніка».

Наукові інтереси:

- проблеми теорії та практики технології виробництва на підприємствах харчової промисловості;

- мінітехнології на підприємствах готельно-ресторанного господарства;

E-mail: andrey11081968@ukr.net

Стаття надійшла до редакції 29.01.2020. 